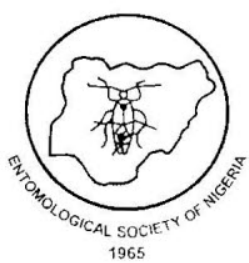

\title{
Insecticidal Efficacy of Raw Diatomaceous Earth, and Jatropha curcas Seed Powder alone, and in Combination against Callosobruchus subinnotatus (Pic.) (Coleptera: Chrysomelidae) in Stored Bambara Nut (Vigna subterranea L. Verdc.) Seeds
}

\author{
*AUDU, A.,' IBRAHIM, N. D. AND LAWAL, M. ${ }^{2}$ \\ 'Department of Agricultural Technology, Ramat Polytechnic, Maiduguri, Nigeria. \\ ${ }^{2}$ Department of Biochemistry, Usmanu Danfodiyo University, Sokoto, Nigeria
}

\begin{abstract}
Nig. J.Entomol. 33:73-82(2017)
ABSTRACT: Laboratory bioassay were conducted to assess the insecticidal efficacy of raw diatomaceous earth (RDE), Jatropha curcas seed powders (ISP) alone and in combination against Callosobruchus subinnotatus in stored bambara mut seeds. The study was carried out under ambient laboratory conditions at $30 \pm 2{ }^{\circ} \mathrm{C}$ and $55 \pm 4 \%$ relative humidity using Completely Randomized Design. The seeds were admixed with the RDE, JSP each at three dose rates as unitary (RDE: $0.5,1.0$ and $1.5 \mathrm{~g} / 100 \mathrm{~g}$ ) and (JSP: $0.5,1.0$ and $2.0 \mathrm{~g} / 100 \mathrm{~g})$ and their binary combination at $(0.5+0.5,1.0+1.0$, $1.5+2.0 \mathrm{~g} / 100 \mathrm{~g}$ ). Actellic ${ }^{k}$ dust at the rate of $2.0 \mathrm{~g} / \mathrm{kg}$ and untreated control were used as positive and negative controls, respectively. Each glass jar $(500 \mathrm{ml})$ was later infested with 30,1 -2-days old $C$. subinnotatus of mixed sexes. Adult mortality was assessed from 24 hours to 96 hours after treatment (HAT). $F_{1}, F_{2}$ adult emergence at 32 and 74 days after treatment (DAT) and percentage seed damage and weight loss were assessed after 90 days. The germination of bambara nut seeds were evaluated at the beginning (before infestation) and after 90 days of treatments and infestation. The results revealed that binary combination of test powders were most effective than either RDE or JSP as unitary applications. The highest dose rates of the binary combination resulted in $100 \%$ adult mortality at 72 HAT. Similarly, all treatments demonstrated reduced mean number of $F_{1}, F_{2}$ adult emergence, sced damage and weight loss compared to the untreated control. Significantly, higher germination percentage was recorded in all treatments before infestation. However, after 90 days of treatments and infestation, the germination capacity of treated seeds decreased, which was significantly different from the untreated control. Bambara nut seeds treated with binary combination gave the best protection against $C$. subinnotatus and thus can be incorporated into integrated stored pest management.
\end{abstract}

Keywords: Raw diatomaceous earth, Jatropha curcas seeds, Callosohruchus subinnotatus, Unitary, Binary combination.

\section{INTRODUCTION}

Bambara nut (I igna subterranea L. Verde.) is an indigenous grain legume grown mainly by subsistent farmers in arid parts of sub-Saharan Africa. In much of Africa, bambara nut is the third most important food legume after cowpea

*Corresponding author

l:-mail: abdullahiauducagmail.com and groundnut(Hillocks et al., 2012; Mkandawire, 2007). Bambara nut is important for smallholders and their households because the seeds are an important source of food, highly nutritious, high in protein (16-25\%) and valued for its economic importance (Heller et al., 1997; Hillocks et al., 2012).

The seeds (shelled nuts) are very susceptible to insect infestation both in the field and store (Obeng-Oforiand Dankwah, 2002). 
Callosobruchus attacks bambara nuts in almost all countries of West Africa (Applebs and Credland. 2001: Haines, 1991). The adults lay their eggs on the pod or seed surface, and the larva then burrows into the seed. dereloping and feeding on the cotyledons before subsequently emerging as an adult (Haines, 1991: Appleby and Credland, 2001: Haines, 1991). Development of C. subinnotutus from egg to adults range from 28 to 35 days depending upon temperature and relative humidity (Haines, 1991;Lale, 2002).

Callosolnruchussuhinnotatus causes significant qualitative and quantitative losses in stored seeds ranging from 30 to $40 \%$ in Nigeria and $50 \%$ in Ghana (Appleby and Credland, 2001; Colobet al., 1999; Haines, 1991; Oparaeke and Bunmi, 2006).

Broad spectrum synthetic insecticides are often used for protecting stored bambara nuts. However, these insecticides are not readily available to farmers due to high cost of procurement, adulteration, risk to the user, development of resistant pest strains, toxicity to non-target organisms and toxic residues left in the protected sceds (Obeng-Ofori and Dankwah, 2002; Oparaeke and Bunmi, 2006). Therefore, the search for an option that can give satisfactory protection and yet be safe and ecologically friendly becomes imperative. Among promising alternatives are diatomaceous earth and plant-derived insecticides. Diatomaceous earth (DE) has low toxicity to mammals and it can be applied without specialized equipment; it kills insects by absorption of cuticular wax leading to water loss and desiccation (Korunic, 1998). Several DE formulations have been evaluated as grain protectants and many of them are now commercially available (Athanassiou et al., 2003: Subramanyam and Roesli. 2000).

Raw diatomaceous Earth (RDE) has been found in Northem Nigeria in large deposits (Nwaubani et al., 2014: Otitodun et al.. 2015: RMRDC. 2009). It can be used to control Rhyzopertha dominica (F.). Sitophilus oryzae (I..) and Tribolium astanemm (Herbst.) effectively on stored grains and its efficacy is comparable to many commercial DEs formulations (Kabire't al. 2011, 2013: Nwaubani e'tal., 2014).

Physic nut, Jatrophacurcas (Linn.)

[Euphorbiaceae], is a multipurpose shrub reaching a height of up to $8 \mathrm{~m}$ (Keith. 2000). It is a native of tropical America. but now thrives in many parts of the trepics and sub-tropics in Africa Asia(Silvactal.,2012). The kernels of the fruit are pressed to give Jatropha oil that has been used for decades as a raw material for subsistent and commercial soap making. Its rural industrial usage includes lubrication, soap and candle making. furniture varnish and dyeing (Tigere et al., 2006). Dried ground seeds. Lat extracts, pericarp powders, seed powders, leaf powders and seed oils of $J$. curcas have been reported to be effective against stored insect pests (Jide-Ojo and Ojo, 2011: Negbenebor et al. 2016: Silva et al., 2012). The main biocidal activities of $J$. curcas is due to the phorbol ester (tetracyclic diterpenoid) (Derappaetal.2011).

Many researchers have shown the potential of combining DEs with other IPM-compatible control methods (Arthur. 20)3: Athanassiou, 2006; Athanassiou and Steenberg, 2007; Ceruti et al., 2005; Otitodun et al.. 2015; Yang e't al., 2010). However, there is dearth of information regarding the combination of RDE and Jatropha seed powders against Cubinnotatus infesting stored bambara nut secus. Therefore, this study cvaluated the efficac of RDE, JSP alone and in combination agains subinnotatus in stored bambaranutseeds.

\section{MATERIAGAND METHODS}

\section{Study Site, Test to toterials and Insect Culture}

The study was conducted in the Agricultural Biology Laboratory, Department of Crop Science, Usmanu Danfodiyo University, Sokoto (UDUS), Nigeria under ambient conditions (30) \pm ' C and $55 \pm 4 \%$ relative humidity). Seeds of $J$. curcas. obtained from mature fruits collected from the Teaching and Research farm of UDUS, were dehulled, and the kernels air-dried for 15 days under ambient conditions. Dried kernels (3 $\mathrm{kg}$ ) were milled using Binatone electric mill (Model BL $(j-450)$ and the powder sieved with $0.2 \mathrm{~mm}$ Endecotts siere before storage in airtight glass jars. RDE obtained as crude, soft and chalky rock from the Department of Geology, Unirersity of Maiduguri, Nigeria, was similarly milled, sieved and stored in glass jar. Seeds of 
Ka'aro. a variety of bambara nut susceptible to C: suhinnotutus, were obtained from farmers in Tambural Local Goremment Area, Sokoto State. The synthetic insecticide used, pirimiphos-methyl (Actellic 20,0D), was purchased from an agrochemical marketer at Kaduna.

Infested bambara nut seeds purchased from Kara market in Sokoto were sieved and the adult C. subinnotatus collected used to start laboratory culture in $1-\mathrm{L}$ glass jars containing $500 \mathrm{~g}$ of Ka'aro bambara nut seeds which had been disinfested at $60^{\circ} \mathrm{C}$ for 1 hour in a hot air oven (Gallenkamp") (Obeng-Ofori and Dankwah, 2002). Each jar was infested with 200 unsexed adults and covered with a lid having wire mesh centre for aeration. After seven days, all insects were removed and the jars were observed for emergence of new adults which were used for the test.

\section{Bioassay}

One hundred grams of Bambara nut seeds was weighed into $500 \mathrm{ml}$ glass jar and admixed separately with $0.5,1.0,1.5 \mathrm{~g}$ of each (RDE, JSP) or their binary combinations at the dose rates of $0.5+0.5,1.0+1.0$, and 1.5+2.0. Actellic $2 \%$ Dust (Pirimiphos-methyl) at $2 \mathrm{~g} / 100 \mathrm{~g}$ seeds was used as a standard. Untreated seeds served as control. The jars were shaken manually for five minutes to ensure uniform coating of the seeds with the treatments. The seeds were then infested with 1-2 day-old adults of mixed sex (30 adults per jar). and each jar was covered with a perforated lid lined with wire mesh to prevent escape of the insects and facilitate ventilation. The experiment was set up in a completely randomized design and each treatment was replicated three times. Mortality was assessed at 24. 48.72 and 96 hours after treatment. Adult insects were considered dead when probed with a blunt probe and there were no movements. The experimental set up was kept undisturbed on the laboratory work bench for $F_{1}$ and $F_{2}$ progeny cmergence at 32 and 74 days after treatment and infestation. After three months. seed damage and weight losswere determined.

\section{Germination tests}

Two germination tests were performed. The tirst was carried out after treatments with RDE, ISP and their binary combinations without infestation by $C$. subinnotatus. Whereas the second test was performed after 90 days on treated seeds and infestation by C. subinnotatus. Twenty seeds were selected randomly from each treatment and placed in glass Petri dishes, labelled and left on a laboratory bench. Each Petri dish was lined with Whatman No 1 filter paper and kept moistened throughout the experiment. Each treatment was replicated three times and arranged in a completely randomized design (CRD). Seeds were considered to have germinated when the radicle emerged from the seed coat. Emerged seedlings were counted and recorded after five days and germination percentage was calculated according to ISTA (1996).

\section{Data Analysis}

Data collected were expressed as percentages. Data on adult mortality were first corrected for mortality in the controls using the Abbott's (Abbott, 1925) formula. Data on corrected mortality, seed damage, weight loss assessment and germination were arcsine-transformed. Data on number of progeny were square root $\sqrt{ }(x+0.5)$ transformed. These were then subjected to one analysis of variance (ANOVA) using Statistix 8.0 software. Where significant differences existed, treatment means were separated using TukeyKramerHSD test at $p<0.05$ (Zar, 1999).

\section{RESULTS}

Table 1 shows the percentage mortality of adult ( $\therefore$ subinnotutus in bambara nut seeds treated with RDE, JSP alone and their binary combination. The result showed that, generally, adult mortality increased with increase in the dose rates and exposure time. Raw DE alone and JSP alone as well as their binary combinations caused significant mortality to adult C. suhinnotatus compared to the untreated controls. The lowest dose rate of $\mathrm{RDE}$ alone (0.5g $100(g)$ resulted in $(28.9 \%)$ adult mortality 24 hours after treatment (HAT), which was not significantly different $(p>0.05)$ from the mortality due to JSP alone $(20.0 \%)$ at the same 
dose rate. Similarly, their binary combinations caused higher adult mortality ranging from (43.3-53.3\%). At 48 HAT, Actellic ${ }^{*} 2 \%$ dust $(92.2 \%)$ was the most effective against $C$. subinnotutus when compared with the untreated control $(5.6 \%)$, which was not significantly different $(p>0.05)$ from some of the treatments. At 72 and 96 HAT, the highest dose rate of the binary combination $(1.5+2.0 \mathrm{~g} / 100 \mathrm{~g}$ seed $)$ had the highest percentage adult mortality (100\%) and the least adult mortality $(6.7 \%)$ was recorded on the untreated control, which were significantly different $(p<0.05)$ from the rest of the treatments (Table 1).

Table 2 represents the effect of treating bambara nut seeds with raw diatomaceous earth

Table 1: Effect of raw diatomaceous earth, Jatropha seed powders (alone and in combination) with percentage mortality of adults $C$. subinnotatus in bambara nut seeds

\begin{tabular}{|c|c|c|c|c|c|}
\hline \multirow{2}{*}{ Treatments } & \multirow{2}{*}{$\begin{array}{c}\text { Dose rates } \\
(\mathrm{g} / 100 \mathrm{~g} \text { seeds })\end{array}$} & \multicolumn{4}{|c|}{ Mean $(\% \pm \mathrm{SE})$ mortality hours after treatments } \\
\hline & & 24 & 48 & 72 & 96 \\
\hline RDE & 0.5 & $28.9 \pm 1.1^{\text {de }}$ & $57.8 \pm 1.1^{\mathrm{cd}}$ & $70.0 \pm 1.9^{\mathrm{bcd}}$ & $70.0 \pm 1.9^{\mathrm{c}}$ \\
\hline RDE & 1.0 & $32.2 \pm 1.1^{\text {cde }}$ & $58.9 \pm 2.2^{\mathrm{cd}}$ & $71.1 \pm 1.1^{\text {bcd }}$ & $78.9 \pm 1.1^{\mathrm{bc}}$ \\
\hline RDE & 1.5 & $38.9 \pm 2.9^{b c d}$ & $60.0 \pm 1.9^{c}$ & $72.2 \pm 1.9^{\text {bcd }}$ & $81.1 \pm 2.9^{\mathrm{hc}}$ \\
\hline JSP & 0.5 & $20.0 \pm 1.4^{\mathrm{c}}$ & $33.3 \pm 3.8^{\mathrm{d}}$ & $50.0 \pm 1.9^{\mathrm{d}}$ & $68.9 \pm 1.9^{c}$ \\
\hline ISP & 1.0 & $31.1 \pm 2.9^{\mathrm{cdc}}$ & $53.3 \pm 1.9^{\mathrm{cd}}$ & $64.7 \pm 0.4^{\mathrm{cd}}$ & $72.2 \pm 2.2^{\mathrm{c}}$ \\
\hline JSP & 2.0 & $34.4 \pm 1.1^{\text {bcde }}$ & $58.8 \pm 2.9^{\mathrm{cd}}$ & $66.7 \pm 0.2^{\mathrm{cd}}$ & $74.4 \pm 1.1^{\mathrm{c}}$ \\
\hline RDE +JSP & $0.5+0.5$ & $43.3 \pm 1.9^{\text {bcd }}$ & $65.5 \pm 2.2^{\mathrm{bc}}$ & $83.3 \pm 1.9^{\text {abcal }}$ & $85.7 \pm 1.1^{\mathrm{bc}}$ \\
\hline RDE+JSP & $1.0+1.0$ & $50.0 \pm 1.9^{\mathrm{abc}}$ & $75.5 \pm 2.2^{\mathrm{abc}}$ & $84.4 \pm 2.9^{a b c}$ & $88.9 \pm 1.1^{b c}$ \\
\hline $\mathrm{RDE}+\mathrm{JSP}$ & $1.5+2.0$ & $53.3 \pm 1.9^{\mathrm{ab}}$ & $86.7 \pm 1.9^{\mathrm{ab}}$ & $100.0 \pm 0.0^{\mathrm{a}}$ & $100.0 \pm 0.0^{\mathrm{a}}$ \\
\hline Actellic $\mathbb{R} 2 \%$ dust & 2.0 & $68.9 \pm 0.4^{a}$ & $92.2 \pm 2.2^{\mathrm{a}}$ & $96.7 \pm 0.0^{\mathrm{ab}}$ & $97.8 \pm 1.1^{\mathrm{ab}}$ \\
\hline Untreated control & 0.0 & $5.6 \pm 2.9^{f}$ & $5.6 \pm 2.9^{\mathrm{c}}$ & $6.7 \pm 1.9^{c}$ & $6.7 \pm 1.7^{\mathrm{d}}$ \\
\hline
\end{tabular}

Means followed by different superseript within columns are significantly different using Tukey - Kramer HSD test at $\mathrm{P}<0.05$.

RDE $=$ Raw Diatomaceous Earth, JSP $=$ Jatropha Seed Powder

Table 2: Effect of treating bambara nut seeds with raw diatomaceous earth, Jatropha seed powders (alone and in combination) with adult $C$. subinnotatus emergence

\begin{tabular}{|c|c|c|c|}
\hline \multirow{2}{*}{ Treatments } & \multirow{2}{*}{$\begin{array}{l}\text { Dose rates } \\
(\mathrm{g} / 100 \mathrm{~g} \text { seeds })\end{array}$} & \multicolumn{2}{|c|}{ Mean number of adult emergence $(\% \pm \mathrm{SE})$} \\
\hline & & $F_{1}$ adult & $\mathrm{F}_{2}$ adult \\
\hline$\overline{\mathrm{RDE}}$ & 0.5 & $18.7 \pm 0.9^{16 c}$ & $21.0 \pm 1.1^{\mathrm{Bcul}}$ \\
\hline RDE & 1.0 & $14.7 \pm 0.3^{\mathrm{hadl}}$ & $15.7 \pm 1.7^{\text {hod }}$ \\
\hline RDE & 1.5 & $13.3 \pm 0.9^{\text {cil }}$ & $14.0 \pm 1.0^{\mathrm{cat}}$ \\
\hline ISP & 0.5 & $22.0 \pm 1.5^{\mathrm{b}}$ & $27.3 \pm 2.0^{\mathrm{h}}$ \\
\hline JSP & 1.0 & $16.3 \pm 0.3^{\text {had }}$ & $25.7 \pm 2.6^{\mathrm{bc}}$ \\
\hline JSP & 2.0 & $15.7 \pm 1.8^{\text {hicd }}$ & $20.3 \pm 2.9^{\text {had }}$ \\
\hline RDE+ISP & $0.5+0.5$ & $12.7 \pm 0.9^{\mathrm{ct} t}$ & $19 .\left(0 \pm 1.2^{\text {had }}\right.$ \\
\hline $\mathrm{RDE}+\mathrm{JSP}$ & $1.0+1.0$ & $11.3 \pm 1.2^{\mathrm{cd}}$ & $17.3 \pm 1.4^{\text {bid }}$ \\
\hline RDE+JSP & $1.5+2.0$ & $9.7 \pm 1.3^{1}$ & $11.0 \pm 1.2^{4}$ \\
\hline Actellic $2 \%$ dust & 2.0 & $1.3 \pm 0.3^{\circ}$ & $3.0 \pm 0.1^{\circ}$ \\
\hline Untreated control & 0.0 & $97.7 \pm 1.2^{11}$ & $112.7 \pm 1.4^{\prime \prime}$ \\
\hline
\end{tabular}

Means followed by different superseript within columns are significantly different using Tukey - Kramer HSD test at $P<0.05$.

RDE $=$ Raw Diatomaceous Earth. ISP $=$ Jatropha Seed Powder 
and Jatropha seed powders (alone and in combination) on the mean number of adult $C$. suhinnotatus emergence. Adult emergence in all treatments was significantly lower than the untreated control. The number of emerging $F_{1}$, $\mathrm{F}$ : adult progeny reduced with increased dose rate of all treatments. The binary combinations reduced adult progeny emergency more than RDE or JSP applied alone, with RDE+JSP at dose rate of $1.5 \mathrm{~g}+2.0 \mathrm{~g} / 100 \mathrm{~g}$ being more potent and was significantly different $(p<0.05)$ from Actellic 2\% dust.

The effect of raw diatomaceous earth and, Jatropha seed powders (alone and their binary

Table 3: Effect of raw diatomaceous earth, Jatropha seed powders alone and in combination on the damage and weight loss caused by $C$. subinnotatus in bambara nut seeds

\begin{tabular}{llll}
\hline \multirow{2}{*}{ Treatments } & $\begin{array}{l}\text { Dose rates } \\
\text { (g/100 g seeds })\end{array}$ & \multicolumn{2}{l}{ Mcan percentage seed $( \pm$ SE) } \\
\cline { 3 - 4 } & 0.5 & $25.4 \pm 1.6^{\mathrm{bc}}$ & weight loss \\
\hline RDE & 1.0 & $17.1 \pm 1.1^{\mathrm{cdc}}$ & $15.8 \pm 0.9^{\mathrm{b}}$ \\
RDE & 1.5 & $9.7 \pm 0.6^{\mathrm{ef}}$ & $10.0 \pm 0.7^{\mathrm{bc}}$ \\
RDE & 0.5 & $21.8 \pm 2.9^{\mathrm{bcd}}$ & $6.0 \pm 0.3^{\mathrm{c}}$ \\
JSP & 1.0 & $27.1 \pm 0.6^{\mathrm{b}}$ & $14.0 \pm 2.1^{\mathrm{b}}$ \\
ISP & 2.0 & $14.5 \pm 2.0^{\mathrm{def}}$ & $16.4 \pm 1.1^{\mathrm{b}}$ \\
JSP & $0.5+0.5$ & $18.2 \pm 2.4^{\mathrm{bcde}}$ & $9.0 \pm 1.5^{\mathrm{bc}}$ \\
RDE+JSP & $1.0+1.0$ & $14.5 \pm 1.9 \mathrm{~d}^{\mathrm{cf}}$ & $9.2 \pm 0.8^{\mathrm{bc}}$ \\
RDE+JSP & $1.5+2.0$ & $7.1 \pm 0.9^{\mathrm{f}}$ & $5.7 \pm 1.1^{\mathrm{c}}$ \\
RDE+JSP & 2.0 & $1.7 \pm 0.4 \mathrm{~g}$ & $5.7 \pm 1.9^{\mathrm{c}}$ \\
Actellic $(\mathbb{R}) 2 \%$ dust & 0.0 & $50.9 \pm 1.4^{\mathrm{a}}$ & $1.0 \pm 0.2^{\mathrm{d}}$ \\
Untreated control & & & $40.8 \pm 1.2^{\mathrm{a}}$
\end{tabular}

Means followed by different superseript within columns are significantly different using Tukey - Kramer HSD test at $\mathrm{P}<0.05$.

RDE $=$ Raw Diatomaceous Farth, JSP = Jatropha Seed Powder

Table 4: Germination percentage of bambara nut seeds treated with raw diatomaceous earth, Jatropha seed powders alone and in combination and infested with $C$. subinnotatus

\begin{tabular}{|c|c|c|c|}
\hline \multirow{2}{*}{ Treatments } & \multirow{2}{*}{$\begin{array}{l}\text { Dose rates } \\
\text { (g/100 g seeds) }\end{array}$} & \multicolumn{2}{|c|}{ Mean germination percentage $( \pm \mathrm{SE})$} \\
\hline & & Before infestation & 90 days after infestation \\
\hline RDE & 0.5 & $91.7 \pm 1.4^{\mathrm{a}}$ & $58.3 \pm 1.7^{\mathrm{a}}$ \\
\hline RDE & 1.0 & $90.0 \pm 2.9^{a}$ & $60.0 \pm 1.0^{\mathrm{a}}$ \\
\hline RDFE: & 1.5 & $90.0 \pm 2.8^{: 1}$ & $58.3 \pm 1.1^{\mathrm{a}}$ \\
\hline ISP & 0.5 & $91.7=1.7^{\mathrm{a}}$ & $55.0 \pm 1.8^{\mathrm{a}}$ \\
\hline ISP & 1.0 & $91.7 \pm 1.0^{3}$ & $56.7 \pm 1.3^{\mathrm{a}}$ \\
\hline ISP & 2.0 & $91.7 \pm 1.4^{3}$ & $66.7 \pm 1.2^{\mathrm{a}}$ \\
\hline RIDF: ISP & $0.5+0.5$ & $90.0 \pm 1.6^{\mathrm{a}}$ & $70.0 \pm 1.3^{: 1}$ \\
\hline $\mathrm{RIDF}+\mathrm{JSP}$ & $1.0+1.0$ & $93.3 \pm 1.3^{3}$ & $73.3 \pm 1.4^{\prime \prime}$ \\
\hline RDE: ISP & 1.512 .0 & $91.7: 1.7^{: 1}$ & $78.3 \pm 1.5^{\mathrm{a}}$ \\
\hline Actellic R $20 "$ "dust & 2.0 & $91.7-1.6^{\mathrm{a}}$ & $65.0 \pm 1.6^{\mathrm{i}}$ \\
\hline Untreated control & 0.0 & $98.3=1.8^{: 1}$ & $18.3 \pm 1.7^{\mathrm{b}}$ \\
\hline
\end{tabular}

Mcans followed hy differemt superseript within columns ate significantly different using Tukey - Kramer HSD lest at $\mathrm{P}<0.0 .5$. 
combination) on the damage and weight loss caused by $C$. subinnotatus infestation in bambara nut seeds was presented in Table 3. Application of raw diatomaceous earth, Jatropha seed powders alone and their binary combination prevented the infestation and damage of the bambara nut seeds compared to untreated control that suffered significant $(p<0.05)$ seeds damage and weight loss as a result of infestation and feeding activity of $C$. subinnotatus. The highest percentage seed damage $(50.9 \%)$ and weight loss $(40.8 \%)$ was recorded in the untreated control and the lowest seed damage $(1.7 \%)$ and weight loss $(1.0 \%)$ was on Actellic" $2 \%$ dust.

The results on the germination percentage of bambara nut seeds treated with raw diatomaceous earth, Jatropha seed powders alone and their binary combination and infestation by adults $C$. subinnotatus are presented in Table 4. There was no significant difference $(p>0.05)$ between treatments in the germination percentage before infestation by $C$. subinnotatus. The germination test made before infestation with adults $C$. subinnotatus gave a germination percentage ranging from 90.0 to $98.3 \%$ in different treatments (Table 4). The germination percentage varied when bambara nut seeds were infested with $C$. subinnotatus. Thus, the highest germination percentage $(78.3 \%)$ was recorded in jars treated with the highest dose rates of the binary combination whilst jars containing the untreated control showed the lowest germination percentage $(18.3 \%)$.

\section{DISCUSSION}

There has been some research on the insecticidal activity of raw diatomaceous earth and Jatropha seed powder against insect pests of stored products (Kabir e't al.. 2011, 2013: Nwaubani e't al.. 2014: Otitodun e't al., 2015; Jide-Ojo and Ojo, 2011: Negbenebor et al., 2016: Silva et al., 2012). Howerer. there is paucity of published information on the use of raw diatomaceous earth in combination with Jatropha seed powder against $C$. suhinnotatus. A thanassiou et al., (2009) showed the potential of combining DE with reduced-risk substances.
The results fiom the study showed that raw diatomaceous earth or Jatropha seed powder alone and their binary combination have insecticidal effects against adult $C$. subinnotatus causing adult mortality between 24 and 96 hours after treatments. However, higher adult mortality was recorded in the binary combination than either treatment alone. Adult mortality increased with increasing dose rates and exposure periods. Thus, 72 hour exposure resulted in increased adult mortality.

The mode of action for the increased activity of raw diatomaceous earth plus Jatropha seed powder could be attributed to the presence of different active components in these natural products that synergized each other and enhanced its efficacy. The finding of this study is in agreement with earlier studies which showed that stored grain insect pests including $C$. subinnotatus can be controlled by enhanced DE formulations. For example, Yang et al., (2010) reported that combination of garlic, Allium sativum (L.) essential oil with diatomaceous earth (DE) was significantly more effective than either treatment alone against rice weevils, Sitophilus oryzae (L.) and red flour beetles, Tribolium castaneum (Herbst). Similarly, Michalaki et al., (2006) used Metarhizium anisopliae in combination with SilicoSec at two dose rates, 0.2 and 0.5 $\mathrm{g} / \mathrm{kg}$ of wheat or flour against Tribolium confusum and the highest dose rate, increased larval mortality, in comparison with the fungus alone or in combination after seven days of exposure. Also, our tindings are consistent with the results reported in other studies (Athanassiou et al., 2003, 2008: Ceruti et al., 2005: Otitodun et cil., 2015).

Raw diatomaceous earth or Jatropha seed powder alone and their binary combination significantly reduced progeny production on treated seeds compared to untreated control. This suppression of progeny production was likely caused by inhibited oriposition or toxicity of these treatments to eggs. This is in agreement with Yang et al., (2010) who reported significant reduction in different life stages of $S$. oryzae in grains treated with garlic oil combined with DE. This is also in agreement 
with the findings of Ofuya el al.. (2015) who found that binary mixture of Piper guincense seed powder and DE significantly reduced oviposition and progeny by C. maculatus on cowpea.

From the results of this current study, it becomes evident that despite reduced progeny production caused by these treatments, $100 \%$ suppression of progeny production was not achieved, which may be attributed to the ability of female beetles to lay their eggs within the seeds and larvae may not be affected until they reach the adult stage. This agrees with Athanassiou (2006) who reported that Sitophilus oryzae progenies emerged in stored wheat treated with beta cyfluthrin applied in combination with diatomaceous earth where $100 \%$ mortality of exposed adults were recorded.

The germination of bambara nut seeds treated with RDE or JSP alone and their binary combination ranged from 55.0 to $78.3 \%$ after 90 days of treatment and infestation. These results revealed that these treatments did not affect the germination of the bambara nut seeds adversely and this corroborates the results obtained by Obeng-Ofori and Dankwah (2002) who showed that neem seed oils and Actellic ${ }^{\mathbb{B}}$ $25 \mathrm{EC}$ did not affect the germination of bambara nut seeds after 90 days of treatments. This also is in agreement with Mariappan et al. (2013) who reported that seeds protected with Jatropha curcas pelleted with pungam leaf powder and Pongamia pinnata seeds pelleted with neem leaf gave high germination percentage due to effective protection from fungal and insect. Biradar Patil e't cl., (2008) also reported that sweet flag rhizome powder, neem seed kernel pow der, neem oil, nimbicidine, neem leaf powder and deltamethrin were effective in preventing storage insects and maintaining higher seed quality throughout 10 months of storage.

Relying on the foregoing. it can be safely concluded that binary combination of RIDE and JSP are effective in controlling (. suhinnolutus. and could be incorporated into an integrated management of storage pests of bambara nut. Further research is however needed to evaluate these under field conditions and in traditional storage structures.

\section{ACKNOWLEDGEMENTS}

This study was a part of the Ph.D. research of the first author. Special thanks to Dr. B.G.J. Kabir of Department of Crop Protection, University of Maiduguri, for providing the Raw Diatomaceous Earth sample used in the study.

\section{REFERENCES}

Abbott, W.A. (1925). A method for computing the effectiveness of an insecticide. Jounnal of Economic Entomology, 18:265-267.

Adedire, C. O., Obembe, O. M., Akinkurolere, R. O. and. Oduleye, S. O. (2011). Response of Callosobruchus maculatus (Coleoptera: Chrysomelidae: Bruchinae) to extracts of cashew kernels. Journal of Plant Diseases and Protection, 118(2): 75-79.

Appleby, J. H. and Credland, P. F. (2001). Bionomics and polymorphism in Callosobruchus subinnotatus (Coleoptera: Bruchidae). Bulletin of Entomological Research, 91:235-244.

Arthur, F.H. (2003). Optimization of inert dusts used as grainprotectants and residual surface treatments. In: Proceedings of the sith International Conference on Stored Product Protection (Credland P. F, Armitage, D. M., Bell, C.H. Cogan, P. M. and Highley. E. eds.), pp. 629-634.,CAB International, UK.

Athanassiou, C. G. and Steenberg, T. (2007). Insecticidal effect of Beanneria bassiana (Balsamo) Vuillemin (Ascomycota: Hypocreales) in combination with three diatomaceous carth formulations against Sitophilus granarius (L.) (Coleoptera: Curculionidae). Biological Cintrol40:411-416.

Athanassiou, C. G., Kavallieratos, N. G., Vayias, B. J. and Stephou, V. K. (2008). Graluation of a new enhanced diatomaceous earth fomulation for use against the stored product pest. Rhyzopertha dominica (Coleoptera: Bostrychidae). International Intinal of Pest Managemem, 54: 43-49. 
Athanassiou, C. G., Kavallieratos, N. G., Dimizas, C. B., Vayias, B. J. and Tomanovic, Z. (2006). Factors affecting the insecticidal efficacy of the diatomaceous earth formulation Silicosec against adults of the rice weevil, Sitophilus or 1zae (L.) (Coleoptera: Curculionidae). Applied Entomologi and Zoologl; 41:201-207.

Athanassiou, C.G., Kavallieratos, N.G., Tsaganouc, F.C., Vayiasa, B. J., Dimizasa, C. B. and Buchelos, C. T. (2003). Effect of grain type on the insecticidal efficacy of Silicosec against Sitophilus ornzae (L.) (Coleoptera: Curculionidae). Crop Protection 22:1141-1147.

BiradarPatil, C. N. K., Ninganur, B. T., Patil, B. N., Hunje, R. and Awaknavar, J. S. (2008). Effect of botanical seed treatment on storability of wheat. Karnataka Journal of Agricultural Science , 21:361-365.

Ceruti, F. C., Maria, S. and Lazzari, N. (2005). Combination of diatomaceous earth and powder deltamethrin for insect control in stored corn. Revista Brasileira de Entomologia, 49: 580-583.

Demissie, G., Tefera, T. and Tadesse, A. (2008). Efficacy of Silicosec, filter cake and wood ash against the maize weevil, Sitophilus zeamais (Motschulsky) (Coleoptera: Curculionidae) on three maize genotypes. Journal of Stored Products Resecurch, 44:227-231.

Devappa, R.K., Makkar, H.P.S. and Becker, K. (2011). Jatropha diterpenes: A review. Journal American Oil and Chemical Societs: 88: 301-322.

Golob, P., Moss, C., Devereau, A., Goodland, A. D., Andan, F. H., Atarigya, J. and Tran, B.N.D. (1999). Improvements in the Storage and Marketing Quality of Grain Legumes: Final Technical Report. NRI Report 2417, Project R 6503. Natural Resources Institute Chatham Maritime Kent, U. K., 59 pp.

Haines, C.P. (1991). Inseres and Arachnids of Tropical Stored Products: Their Biologl and Identification (2nd edition). Natural Resources Institute, Chatham, Kent, UK. 246 pp.

Heller, J., Begemann, F. and Mushonga, J. (1997). Bambara groundnut (ligna subterranea (L.) Verdc.). In: Promoting the conservation and use of underutilized and neglected crops. Procededings of the Workshop on Conservation and Improvement of Bambara Groundmut (ligna subterranean (L.) Verdc). (Heller. J., Begemann, F. and Mushonga, J. eds.), 14-16 November 1995, Harare, Zimbabwe.

Hillocks, R.J., Bennett, C. and Mponda, O.M. (2012). Bambara nut: A review of utilization, market potential and crop improvement. African Crop Science Journal, 20(1): 1-16.

Ibrahim, N.D., Audu, A., Dike, M.C. and Lawal, M. (2012). Effect of raw diatomaceous earth and plant powders in the control of Callosobruchus subinnotatus (Pic.) infesting stored bambara groundnut seeds. Scientific Journal of Pure and Applied Science, 1:9-16.

Islam, M.S., Hasan, M.M., Lei, C., MuchaPelzer, T., Mewis, I.and Ulrichs, C. (2010). Direct and admixture toxicity of diatomaceous earth and monoterpenoids against the storage pests Callosobruchus maculatus (F.) and Sitophilus oryzae (L.). Journal of Pest Science, 83: 105-112.

Jide-Ojo, C. C. and Ojo, O. O. (2011). Evaluation of the biological effects of leaf extracts of Jatropha curcas against Sitophilus ze'mnais (Coleoptera: Curculionidae). Electronic Jounal of Emirommental, Agricultural and FoodChemistr); 10(5): 2166-2172.

Kabir, B. G. J., Lawan, M. and Gambo, F. M. (2011). Efficacy and persistence of raw diatomaceouscarthagainst Tribolinmencestanem (Herbst) (Coleoptera: Tenebrionidae) on stored maize, sorghum and wheat. Acatemic Jounal of tintomologi: 4:51-58.

Kabir, B. G. J., Lawan, M and Jidda, M. B. (2013). Bioactivity of raw diatomaceous earth against Rhizopertha dominica Fab. (Coleoptera: Bostrichidae): Effects of grain type. dose rate and exposure period. Jemrnal of tericulture and léterinarr Science, 4: 4459.

Kavallieratos, N. G., Athanassiou, C. G., Vayias, B. J. and Maistrou, S. N. (2007). Influence of temperature on susceptibility 
of Tribolium confusum (Coleoptera: Tenebrionidae) populations to three modified diatomaceous earth formulations. Florida Entomologist, 90:616-625.

Keith, O. (2000). A review of Jaropha curcas: an oil plant of unfulfilled promise, Biomass and Bioenergl; 19:1-15.

Korunic, Z. (1998). Diatomaceous carths, a group of natural insecticides. Journal of Stored Products Research, 34: 87-97.

Lale, N.E.S. (2002). Stored Product Entomolog: and Acarologi: in Topical Africa. Mole Publication, Maiduguri, Port Harcourt and Harare, 203pp.

Mariappan, N., Srimathi, P., Sundaramoorthy, L. and. Paramathma, M. (2013). Effect of organic seed pelleting on seed storability andquality seedling production in biofuel tree species. African Journal of Crop Science, 1:024-028.

Mkandawire, C. H. (2007). Review of bambara groundnut production in sub-Saharan Africa. Agricultural Journal, 2:464-470.

Negbenebor, H. E., Makanjuola, W. A. and Denloye, A. A. (2016). Toxicity of seed powder and extracts of Jatropha curcass to three storage beetles. Journal of Tropical Biosciences, 11:22-30.

Nukenine, E. N., Adler, C. and Reichmuth, C. (2007). Efficacy evaluation of plant powders from Cameroon as post-harvest grain protectants against the infestation of Sitophilus zeamais (Motschulsky) (Coleoptera: ('urculionidae). Journal of Plant Disecases and Protection, 114:30-36.

Nukenine, E. K., Goudoungou, J. W., Adler, C. and Reichmuth, C. (2010). Efticacy of diatomaceous earth and botanical powders against the maize weevil, Sitophilus zeamais (Motschulsky) (Coleoptera: Curculionidae) on maize. In: Proceedings of the 10th International Working Conference on Stored Product Protection (Carvalho, M. O.. Fields. P. G.. Adler, C. S.. Arthur, F. H., Athanassiou. C. G., Camplell, J. F.. FleuratLessard, F., Flinn, P. W., Hodges, R. J., Isikber, A. A.. Navarro, S., Noyes. R. T.. Riudavets, J., Sinha, K. K., Thorpe. G. R., Timlick, B. H., Trematerra, P. N. and White, D. G. eds), pp.881-887 held 27th June-2nd
July, Estoril, Portugal.

Nwaubani, S. I., Opit, G. I., Otitodun, G.O. and Adesida, M.A. (2014). Efficacy of two Nigeria-derived diatomaceous earths against Sitophilus or 1 zac'(Coleoptera: Curculionidae) and Rhropertha dominica (Coleoptera: Bostrichidae) on wheat. Journal of Stored Products Research, 59:9-16.

Obeng-Ofori, D.and Dankwah, J.A. (2002). Biological effects of four protectants applied to stored bambara groundnut against infestation by Callosobruchus maculatus (Fab.) (Coleoptera: Bruchidae). Journal of Ghana Science Association 4(2): 41-51.

Ogendo, J. O., Deng, A. L., Belmain, S. R., Walker, D. J. and Musandu, A. A. O. (2004). Effect of insecticidal plant materials, Lantana camara L. and Tephrosia vogelii Hook, on the quality parameters of stored maize grains. Journal of Food Technology in Africa, 9:29-36.

Oparaeke, A. M. and Bunmi, O. J. (2006). Insecticidal potential of cashew (Anacardium occidentale L.) for control of the beetle, Callosobruchus subinnotatus (Pic.) (Bruchidae) on bambara-groundnut (Voandzeia subterranea (L.). Verdc. Archives of Phytopathology and Plant Protection, 39:247-251.

Otitodun, G.O, Opit, G.P., Nwaubani, S.I., Okonkwo, E.U. and Gautam, S.G.(2015). Efficacy of Nigeria-derived diatomaceous earth, botanicals and riverbed sand against Sitophilus oryzae and Rhyzopertha dominica on wheat. African Crop Science Journal, 23: 279-293.

RMRDC (2009). Raw Materials Update, September 2009. An Occasional Bulletin Series of Raw Material Research and Derelopment Council. Federal Ministry of Science and Technology, Nigeria, pp. 7-9.

Silva, G. N., Faroni, L. R. A., Sousa, A. H. and Freitas, R.S. (2012). Bioactivity of Jatropha curcas L. to insect pests of stored products. Jounal of Stored Products Research, 48:111113.

Statistix 8.0. (2007). The Plant Materials Program. Analytical Software. Tallahassee - Florida, United States.

Subramanyam, B.H. and Roesli, R. (2000). Inert dusts. In: Alternatives to Pesticides in 
Stored-Product IPM (Subramanyam, B. H., and Hagstrum, D.W. eds.). pp. 321380. Kluwer Academic Publishers, the Netherlands.

Tigere, T.A., Gatsi, T. C., Mudita, I. I., Chikuvire, T. J., Thamangani, S. and Mavunganidze, Z. (2006). Potential of Jatropha curcas in improving smallholder farmer's livelihoods in Zimbabwe. An exploratory study of Makosa ward, Mutoko
District. Journal of Sustainable Development in 1firicu. 8(3): 1-9.

Yang, N. W., Li, A. L., Wan, F. H., Liu, W. X. and Johnson, D. (2010). Diatomaceous earth enhanees the toxicity of garlic. Allium sutirum, essential oil against storedproduct pests. Journal of Stored Products Resecurch, 46: 118-123.

Zar, J. H. (1999). Biostatistical Analysis. (3rd Ed.). Prentice-Hall, N.I. $718 \mathrm{pp}$.

"Audu, A., 'Ibrahim. N. D. and Lawal, M."

Nigerian Journal of Entomology.

Published by the Entomological Society of Nigeria

wwu:esn.org.ng

ISSN: 0331-0094

Volume 33. 2017

pp 73-82

DOI:10.36108/NJE/7102/33(0190) 